Characteristics of Precipitation in Saskatchewan and Alberta", in which it is apparent that the author's investigations and their results may have a wider application than the merely agricultural (Canadian J. Res., 14, No. 9, Sept. 1936). In previous agricultural meteorological investigations, Mr. Hopkins demonstrated statistically significant correlations between annual variations in rainfall and temperature, and the yield and nitrogen content of wheat crops grown in central and southern Saskatchewan and Alberta. In the present paper, the author gives the results of a study complementary to the previous one, dealing with some average characteristics of the seasonal precipitation in these districts, and also analysing the fluctuations which past experience has shown to occur from year to year in the precipitation at a given place, and from place to place in the same district during a given year. The investigations appear to be based on observations carried on between 1898 and 1934, the stations being Edmonton, Calgary, Battleford and Swift Current. "In spite of irregularities, to be expected in the limited sample of years available," says the author, "the frequency of distribution of seasonal precipitation at the stations showed no gross asymmetry, seasons with precipitation in the vicinity of the average being on the whole more numerous." The average (1916-32) percentage of days on which rain fell showed a distinct seasonal trend during spring and summer, being lowest in April and highest in June. Similar variation was noted in the average amount of rain per rainy day, which was lowest in April and highest in June and July. It would be of interest if in future observations some data could be collected on the subject of the possible influence of the forests on the atmospherical moisture content in these regions.

\section{Plant Pathology in Devon and Cornwall}

The twelfth annual report of the Department of Plant Pathology at the Seale-Hayne Agricultural College, Newton Abbott, Devon, considers the pests and diseases of plants from an essentially local aspect, which should be much appreciated by growers in Devon and Cornwall. Mr. L. N. Staniland, the advisory entomologist, contributes a general section upon the more common pests of farm and garden. $\mathrm{He}$ has made a special study of eelworm troubles. Methods of combating this pest are discussed at considerable length, and a thorough revaluation of the usual hot-water treatment has been made. It has been found that although eelworms are killed by seventeen minutes exposure to a temperature of $110^{\circ} \mathrm{F}$., the technique of commercial treatment varies greatly. The usual period of three hours heating is shown to be inadequate in some cases, and various recommendations as to improved methods are made. $\mathbf{M r}$. A. Beaumont, the advisory mycologist, has made a further detailed study of the relation of potato blight to the weather of Devon, and has separate articles on "Tulip Fire and the Weather", "Snapdragon Rust ; Trials of Resistant Varieties", and "Apple and Pear Fruit-rotting Fungi".

\section{Vital Statistics for England and Wales for 1934}

The text volume of the Registrar-General's Statistical Review of England and Wales for 1934, recently issued, contains the official commentary on the two volumes of vital statistics already published (London: H.M. Stationery Office. 3s. 6d. net). The report deals with the statistics of births, deaths and marriages registered in 1934, estimates of population, and other matters. The estimated population of England and Wales in the middle of 1934 was $40,467,000$ persons, of whom $19,412,000$ were males and $21,055,000$ females. The total is 117,000 , or 0.29 per cent greater than the estimate for the previous year, and 515,000 or $1 \cdot 3$ per cent greater than the population at the census of 1931. The average ages of the estimated population, which are gradually increasing, are 32.4 years for males and $34 \cdot 2$ for females. In addition to reviewing the mortality from various causes, the report also contains several studies of mortality. One of these deals with the handicaps suffered by the winter-born compared with the summer-born child, and another with the mortality rate from pregnancy and child. bearing for the wives of men in various social groups.

\section{Fall in French Birth-Rate}

THE annual number of births in France reached its maximum towards the end of the Second Empire, when it was so high as $1,034,000$ in 1868 . In 1934 it had fallen to 677,000 and in 1935 to about 650,000 , of which nearly 50,000 were the children of foreigners. The birth-rate has therefore diminished by 384,000 or nearly a third, although the population has increased since 1868 by three million immigrants or naturalized persons, which has resulted in increasing the population from 38 to 48 million inhabitants. During the period 1900-35, the birth-rate has decreased by nearly 100,000. The number of births per marriage has decreased even more rapidly. In 1800 the average number of births in France was 4.5 per marriage, at the end of last century it was 3 , and to-day only $2 \cdot 2$, or a diminution of about fifty per cent.

\section{The Value of Experiments on Animals}

ThE autumn issue of the Fight against Disease (24, No. 4), the quarterly journal of the Research Defence Society, contains extracts from the evidence given by Lord Justice Fletcher Moulton before the Royal Commission on Vivisection, 1906-8. The considered opinion of Lord Moulton, whose scientific knowledge and clarity of thought must have materially assisted the Commission in forming an opinion upon the anti-vivisection controversy, should help those who have to address meetings on the question, or have to deal with anti-vivisection propaganda.

\section{Physics in Industry}

AT the meeting at the end of October commemorating the fifth anniversary of the founding of the American Institute of Physics, the replies of fifty leading industrial physicists to the question: what 
training is best for the scientific worker who wishes to enter industry, were summarized by Dr. Oplin, director of research at Kendall Mills, Boston. His summary has been taken up by Science Service, Washington, D.C., and circulated. His principal conclusions are: "Industries need physicists trained in the fields of optics, magnetism and acoustics", and "too little emphasis is placed on these fields in academic training" as "the best known scientists are working on the problems of cosmic rays, atomic disintegration and transmutation" and "students naturally look up to them for guidance". "Some training in engineering courses is advocated for future industrial physicists. Industry finds it better and easier to use a student trained adequately in physics and have him in the plant attain his additional engineering knowledge than to try to give the engineering student the additional knowledge of physics".

\section{R.R.S. Discovery II Survey Party}

CONSIDERABLE concern was caused by the announcement on January 18 from the commanding officer of the R.R.S. Discovery II, that a survey party which had been landed on King George Island, South Shetlands, was missing. Early on the following day, however, the reassuring message was received that the party had been located and had returned to the ship. The Discovery Committee states that the party consisted of : Lieut. R. Walker, R.N.R., chief officer; Dr. J. R. Strong, ship's surgeon ; Dr. F. D. Ommanney, scientific officer; Mr. R. G. Gourlay, third engineer ; Mr. J. Matheson, boatswain's mate; and Mr. J. Dobson, A.B.

\section{Bureau of Human Heredity}

ONE activity contemplated in setting up the Bureau for Human Heredity is the organization of information service for research workers in the subject. The value of such a plan has been demonstrated in the information service already established for workers on Drosophila, etc. Workers are requested, to address to the Bureau a short paragraph describing the work on which they are engaged. These notices will be multiplied and circulated to all those cooperating. In the first instance, this bulletin will be issued every twelve months. Later supplementary bulletins will be issued more frequently. Those using this service are asked to subscribe $5 s$. Communications should be addressed to the Hon. General Secretary, Bureau of Human Heredity, 115 Gower Street, London, W.C.1.

\section{Federal Council on Scientific Management}

AN important step forward in the co-ordination of the varied activities of the many societies connected in some way or other with the several phases of scientific management was taken on January 12, when a British Management Council was formed. After the highly successful sixth International Congress for Scientific Management, held in London during July 1935, a committee was set up under the chairmanship of Dr. E. F. Armstrong both to take all necessary action to ensure the proper representation of Great Britain at the next Congress, to take place in the United States in 1938, and to examine the factors involved in the formation of a national scientific management organization. A scheme of federation has been produced by this committee, and after discussion has met with provisional acceptance from the greater number of the associations concerned, numbering some thirty in all. The objects of the new Federal Council are: "To ascertain and represent both nationally and internationally the views of those bodies concerned in Management in Great Britain, and in particular as its immediate object to enter into relations and to co-operate with similar bodies in other countries, and to act as the representative of its Constituent Members in International Congresses and other activities concerned with Management." Lord Leverhulme has been elected as its first chairman, Dr. E. F. Armstrong as vice-chairman, Mr. G. R. Freeman as treasurer, and Mr. U. Baliol Scott as secretary. The new body is assured of the support and co-operation of the Federation of British Industries. It has an important function to fill and may be expected in time to exert a pronounced influence on the development of the functional management movement in Great Britain.

\section{Botanical Society of America}

Ar its thirty-first annual meeting at Atlantic City, New Jersey on December 20-31, the Botanical Society of America elected the following botanists to be corresponding members: Dr. N. I. Vavilov, director of the State Institute for Experimental Agronomy, Leningrad; Dr. Agnes Arber, sometime fellow of Newnham College, Cambridge; and Dr. Lorenzo R. Parodi, professor of botany in the University of Buenos Aires. The following officers of the Society for 1937 were also elected : President, Prof. Edmund W. Sinnott, Barnard College, Columbia University, New York City; Vice-President, Prof. Loren C. Petry, Cornell University, Ithaca, N.Y.; Secretary, Prof. George S. Avery, jun., Connecticut College, New London, Conn.; Treasurer, Dr. F. E. Denny, Boyce Thompson Institute for Plant Research, Yonkers, N.Y. A new Section for Paleobotany was also organized with the following officers: Chairman, Prof. A. C. Noé, University of Chicargo ; Secretary, W. C. Darrah, Harvard University.

\section{International Congress of Agriculture}

THE seventeenth International Congress of Agriculture will be held at The Hague on June 16-23, 1937, under the patronage of the Queen of the Netherlands. The work of the Congress is divided among eight sections. Three are economic in character, and at The Hague will discuss the means which have been taken to deal with the depression in the agriculture of the Netherlands, the organization of the world butter market, the provision of credit to agriculture, the relation between State planning and agricultural co-operation, the effect on agriculture of the development of artificial wools, cottons and other products. Sections dealing with the technical and 